УДК 811.111’37’373.46’38:[339.138:502.1

DOI https://doi.org/10.26661/2414-1135-2021-82-7

\title{
СЕМАНТИЧНІ ОСОБЛИВОСТІ ТЕРМІНІВ ЕКОМАРКЕТИНГУ В АНГЛОМОВНИХ ПУБЛІЦИСТИЧНИХ ТЕКСТАХ
}

\author{
Гордун С. М. \\ кандидат філологічних наук, \\ асистент кафедри іноземних мов гуманітарних спеціальностей \\ Волинський національний університет імені Лесі Украӥнки \\ пр. Волі, 13, Луцььк, Україна \\ orcid.org/0000-0002-2523-8301 \\ Hordun.Svitlana@vnu.edu.ua
}

\begin{abstract}
Ключові слова: вузькогалузеві терміни, міжгалузеві терміни, зовнішньогалузева лексика, синонімія, терміносистема екомаркетингу, термін, публіичитичний текст.
\end{abstract}

Дослідження термінів грунтується передусім на законах загального термінознавства, одним 3 основних завдань якого $\epsilon$ дослідження вузькогалузевих терміносистем, до яких належить i термінологічна система екомаркетингу - молода терміносистема науки, яка виникла на стику екології, економіки та маркетингу. Зусилля екомаркетингу спрямовані на задоволення потреб людей за допомогою виробництва, реалізації та споживання товарів, послуг, обміну інформації тощо, при цьому вони не порушують екологічної рівноваги й не впливають на здоров’я людей. Досліджувані терміни забезпечують накопичення та трансфер фахової інформації та задовольняють комунікативні потреби спеціалістів цієї галузі. Статтю присвячено дослідженню семантичних особливостей термінів екомаркетингу. Матеріалом дослідження слугують англомовні публіцистичні тексти з екомаркетингу за період 2011-2017 років (обсяг вибірки - 52261 слововживання), які ми вважаємо найважливішими засобами вираження терміносистеми екомаркетингу. Крім того, вважаємо, що сфера функціонування є більш важливою в термінознавстві, адже термін - це мовна одиниця, яка проявляє усі свої властивості й ознаки тільки в разі його вживання в текстах різних жанрів. Дослідження показало, що будь-який публіцистичний текст екомаркетингу містить вузькогалузеві, міжгалузеві, зовнішньогалузеві терміни та загальновживану лексику, причому зауважимо, що газетні статті, порівняно зі статтями спеціальних видань, містять набагато менше термінів усіх груп. Також було встановлено, що в публіцистичних текстах наявна велика кількість термінів-синонімів. Синонімія терміносистеми екомаркетингу проявляє свої особливості, функціонуючи власне в публіцистичних текстах. На основі проведеного аналізу було виділено три типи синонімічних рядіву терміносистемі екомаркетингу, найчастотнішим 3 яких є ряд синонімів, які частково проявляються в публіцистичних текстах. Для впорядкування терміносистеми екомаркетингу важливим $€$ процес уніфікації синонімів, при цьому потрібно дотримуватися критеріїв вмотивованості та абсолютної частоти. Отримані результати нашого дослідження сприятимуть взаєморозумінню науковців у світі та полегшенню процесу передачі інформації. 


\title{
SEMANTIC PECULIARITIES OF GREEN MARKETING TERMS IN ENGLISH PUBLICISTIC TEXTS
}

\author{
Hordun S. M. \\ Candidate of Philological Sciences, \\ Assistant at the Department of Foreign Languages for Humanities \\ Lesya Ukrainka Volyn National University \\ Volia avenue, 13, Lutsk, Ukraine \\ orcid.org/0000-0002-2523-8301 \\ Hordun.Svitlana@vnu.edu.ua
}

Key words: in-disciplinary term, interdisciplinary term, general scientific term, synonym, green marketing terminology system, term, publicistic text.

\begin{abstract}
The analysis of terms is based primarily on the laws of terminology. One of the main tasks of it is to study the terminology systems of a separate branch of knowledge, which includes the green marketing terminology system which is a quite young system of terms and emerged at the intersection of ecology, economics and marketing. Green marketing efforts are aimed at meeting the needs of people through the production, sale and consumption of goods, services, information exchange, etc., while they do not disturb the ecological balance and do not affect human health. Green marketing terms provide accumulation, and transfer of professional information, and meet communicative needs of specialists in this field. The article is devoted to the study of semantic peculiarities of green marketing terms. The material of the research is English publicistic texts, which we consider to be the most important means of expressing the terminology of green marketing. In addition, we believe that the field of functioning is more important in terminology because the term is a linguistic unit that shows all its features and characteristics only when it is used in texts of different genres. The study showed that any publicistic text of green marketing contains in-disciplinary terms, interdisciplinary terms, general scientific terms, and common vocabulary. We should note that newspaper articles, compared to articles in scientific magazines, contain much fewer terms. It was also found that there are a large number of synonymous terms in publicistic texts. Synonyms of green marketing show their peculiarities only when they are a part of publicistic texts. Taking into consideration the results of our analysis, three groups of synonyms were identified in the green marketing terminology, the most frequent of which is a group of synonyms, which are partially used in publicistic texts. The process of unification of synonyms is important for the green marketing terminology, and it is necessary to adhere to the criteria of term motivation and absolute frequency of term usage. The results of our study will promote mutual understanding between scientists around the world and facilitate the process of information transfer.
\end{abstract}

Постановка проблеми. Нині глобальна екологічна криза суттєво впливає на усі сфери життя людини й спонукає людей до свого роду екологізації науки та практичної діяльності. Оскільки усі зміни в суспільстві так чи інакше відбиваються на мові, можна спостерігати виникнення величезної кількості термінів, пов'язаних зі сталим розвитком і екомаркетингом зокрема. Саме терміни дуже часто стають об'єктом лінгвістичних досліджень, адже коректне використання термінів є запорукою взаєморозуміння між спеціалістами, а це своєю чергою буде сприяти швидшому розв'язанню екологічних проблем.
Проблемами вузькогалузевих терміносистем займалися такі відомі термінознавці, як Б.М. Головін, Т.Р. Кияк, В.М. Лейчик, М.М. Володіна, Ю.А. Зацний тощо. Так, англомовні фахові тексти 3 охорони довкілля досліджувала М.Я. Саламаха. Е.Т. Дерді вивчала юридичні тексти, С.А. Вискушенко - тексти тваринництва, а O.I. Гутиряк цікавиться терміносистемою маркетингу. На матеріалі німецької мови написано роботи C.I. Вовчанської (тексти маркетингу), О.М. Бондар (тексти екологіï), О.М. Ріба (тексти 3 нафтової промисловості), Р.Б. Шевців (тексти економічних наук). Однак терміносистема екомарке- 
тингу досі $є$ не уніфікованою та потребує глибокого аналізу.

Мета статті полягає в аналізі семантичних особливостей термінів екомаркетингу англомовних публіцистичних текстів, яка досягається вирішенням таких завдань: 1) розділити усі виявлені в текстах терміни на вузькогалузеві, міжгалузеві та загальнонаукові; 2) проаналізувати випадки синонімії термінів екомаркетингу в публіцистичних текстах і запропонувати шляхи уніфікації терміносистеми екомаркетингу.

Об'єктом дослідження є терміни терміносистеми екомаркетингу в публіцистичних англомовних текстах.

Предметом аналізу виступають семантичні особливості термінів екомаркетингу в англомовній публіцистиці.

Виклад основного матеріалу дослідження. Тексти різних жанрів містять велику кількість різної лексики, однак основою будь-якого тексту $\epsilon$ загальновживана лексика, яка забезпечує зв'язність тексту та робить його зрозумілим широкому колу читачів. Англомовні публіцистичні тексти екомаркетингу, окрім власне термінів екомаркетингу, містять і терміни інших дисциплін, загальнонаукові терміни та загальновживану лексику. Тому лексичні одиниці публіцистичних текстів екомаркетингу поділяються на чотири групи:

1) вузькогалузеві терміни представлені групою термінів, які належать тільки до конкретної терміносистеми, розраховані на фахівців окремої професійної сфери знань і зберігають свою вузькогалузеву маркованість [1, с. 143]. Ця група термінів є ядром терміносистеми екомаркетингу;

2) міжгалузеві терміни - це терміни, які використовуються в різних терміносистемах. Так, у публіцистичних текстах екомаркетингу це терміни суміжних дисциплін - екології, економіки, маркетингу, техніки тощо: climate change, global warming, energy crisis, Fenton's reagent, ozonation тощо. За словами О.М. Бондар, такі терміни здатні переходити до категорії загальнотехнічних чи загальнонаукових лексичних одиниць, а також поповнювати загальнолітературну лексику [1, с. 143];

3) зовнішньогалузеву лексику репрезентують терміни, які належать до інших терміносистем і стосуються загального термінологічного фонду наук (терміни політики, релігії, культури тощо). Зовнішньогалузева лексика знаходиться на периферії терміносистеми екомаркетингу і характеризується високим ступенем абстракції і міждисциплінарним характером;

4) нефахова лексика, або загальновживана, за С.А. Вискушенко, виступає сукупністю всіх мовних засобів загальновживаної мови і не пов'язана 3 жодною професійною галуззю знань чи людської діяльності. Такі лексичні одиниці познача- ють предмети, явища, дії, ознаки, які вживаються в повсякденному житті усіма користувачами відповідної мови та уможливлюють загальнонаціональне спілкування [3].

Так, проаналізувавши заголовки 38 англомовних статей, ми виявили 21 термінологічну одиницю терміносистеми екомаркетингу, які складаються 336 терміноелементів (усі відібрані заголовки містять 267 слів). Використовуючи ці дані, можемо підтвердити той факт, що більшу частину публіцистичних текстів становлять загальновживані слова, цим текстам не притаманний високий ступінь використання термінів у заголовках, що Р. Уолсі пояснює тим, що загальні журнали та газети орієнтуються на широке коло споживачів [16, с. 256].

За допомогою програми Voyant Tools [15] ми проаналізували тексти газет та журналів і побачили різницю між статтями. Так, ми визначили, що в нашій вибірці публіцистичних газетних текстів найчастотнішими словами є такі: energy 130; says - 113; waste - 110; water - 110; new - 61; plastic - 56; use - 51; companies - 47; coffee - 45; food - 44; materials - 44; sustainable - 44, терміноелемент greеn - 49. Як бачимо, переважають серед найчастотніших слів власне загальновживані слова, що цілком підтверджує думку про те, що газетні статті орієнтовані на звичайного читача [2, c. 149].

Натомість кількість термінів екомаркетингу в журнальних статтях набагато більша, ніж у газетних статтях, про що свідчать дані вибірки програми Voyant Tools [15]: green (261), environmental (179), marketing (156), consumers (98), environment (94), eco (93), energy (90), products (88), innovation (68), practices (68), research (68), consumption (67), feedback (64), waste (61), industry (58), householders (56), product (56), sustainability (54) тощо. Як бачимо, майже всі слова $€$ або термінами, або терміноелементами багатокомпонентних термінів екомаркетингу, що пояснює високу інформативність публіцистичних текстів у спеціалізованих журналах.

Ще однією семантичною особливістю термінів екомаркетингу в англомовній публіцистиці $\epsilon$, насамперед, функціонування термінів-синонімів, які загалом вважаються небажаним явищем у терміносистемах, оскільки вони порушують системність терміносистеми, що перешкоджає процесу іiі нормування.

Проаналізувавши синонімічні ряди терміносистеми екомаркетингу за критерієм абсолютної частоти в корпусах, ми виокремили 253 терміни-синоніми, які утворюють 95 синонімічних рядів, які ми поділяємо на:

1) синонімічні ряди, які повністю проявляються в англомовній публіцистиці екомаркетингу, 
тобто усі терміни, які входять до синонімічного ряду, зустрічаються в корпусі; наприклад, термін carbon emissions зустрічається в корпусі 416 разів, а його синонім $\mathrm{CO}_{2}$ emissions - 209. Зауважимо, що таких рядів найб̆ільше, а саме 44 ;

2) синонімічні ряди, які частково проявляються в публіцистичних текстах, тобто один або кілька членів ряду не були виявлені в корпусі, наприклад: термін waste-to-energy зустрічається 8 разів, а його синонім energy-from-waste - 0 . Таких рядів налічується 36 ;

3) синонімічні ряди (15 рядів), які повністю не були виявлені в терміносистемі екомаркетингу, наприклад, синонімічний ряд green syndicalism eco-syndicalism [2, c. 150].

Нульову абсолютну частоту терміна-синоніма або цілого синонімічного ряду можна пояснити такими факторами:

1) ці терміни можуть належати до рідко вживаних вузькогалузевих термінів екомаркетингу, які більше притаманні науковим текстам, а не публіцистичним;

2) деякі терміни є вже застарілими й через це не зустрічаються в нашому матеріалі. Однак ми не маємо права вилучати їх із терміносистеми екомаркетингу, оскільки вони зафіксовані в лексикографічних джерелах, а тому цілком можуть вживатися в різностильових текстах [2, с. 151].

Усі термінологічні синоніми екомаркетингу ми також поділяємо за семантичною ознакою на два типи: терміни-дублети (сурядний синонімічний зв'язок) і відносні синоніми (субпідрядний синонімічний зв'язок). Розмежувати ці типи термінів можна, лише проаналізувавши їх у тексті. Терміни-дублети, або абсолютні синоніми, як уже зазначалося, майже не відрізняються своїм семним складом іє взаємозамінними в контексті. Сюди належать усі синонімічні ряди, які складаються 3 повного та скороченого терміна, а також деякі інші терміни, наприклад, high efficiency particulate air filters - HEPA filters, ecofriendly product-green product.

Водночас терміни другого типу зв'язку є важливими чинниками у процесі виконання інформаційної функції терміна, тобто в разі вживання певного синоніма із синонімічного ряду виокремлюються ознаки, що є характерними лише для нього [4], наприклад, clean car-green vehicle. Зауважимо, що в багатокомпонентних синонімічних рядах між різними їх одиницями можуть існувати як один, так і другий тип зв'язку; наприклад, у синонімічному ряді pay-as-you-throw - PAYT - unit-based pricing volume-based pricing очевидним $є$ те, що перших два його компоненти є термінами-дублетами, а інші члени $є$ відносними синонімами.

Як уже зазначалося, синонімія не є бажаною в терміносистемах, а тому потребує впорядкування. У доборі нормативного терміна потрібно користуватися такими принципами: термін має відповідати всім вимогам літературної мови, не порушувати системних зв'язків у межах терміносистеми й мови загалом, мати високу частоту вживання, бути абсолютно вмотивованим та мати статус міжнародного [9, с. 63].

Щоб вибрати 3 групи термінів-синонімів найвиправданіший, варто користуватися також параметрами вмотивованості [6]. Для цього нам потрібно проаналізувати лексичне значення (дефініцію) терміна і визначити, який варіант терміна найбільш відповідає вимогам професійного спілкування, тобто який є більш мотивованим. Також потрібно звертати увагу на те, чи відповідає внутрішня форма терміна його лексичному значенню. Внутрішня форма терміна представлена морфемною структурою й «утворює не просту сукупність смислів та узусу ііі складників», а визначену систему взаємопов'язаних і взаємозумовлених елементів [8, с. 140]. Внутрішня формаце системна характеристика слова чи словосполучення, яка виконує роль «перехідного містка» від звукової оболонки до значення» [7, с. 247].

Наприклад, у терміносистему екомаркетингу увійшли терміни екології pollute та contaminate. Cambridge Learner's Dictionary подає такі визначення цих термінів: contaminate - to make something less pure or make it poisonous: [12]; pollute - to make an area or substance, usually air, water, or soil, dirty or harmful to people, animals, and plants, especially by adding harmful chemicals [12]. Дефініція терміна pollute означає, що забруднення відбувається внаслідок певної діяльності людини, а contaminate такого натяку не має, тобто забруднення може бути й природного походження. Отже, обидва терміни та їх похідні contamination - pollution, contaminantpollutant мають право на існування.

Як додатковий критерій уніфікації синонімів ми пропонуємо використовувати частоту вживання цих термінів за даними Корпусу сучасної американської англійської мови (The Corpus of Contemporary American English) [13] та Британського національного корпусу (The British National Corpus) [11].

Так, термін pollute у вибірці з цих корпусів за 2000-2015 роки (обсяг вибірки - 194256832 слововживань) зустрічається 251 раз, а contaminate241 , тобто варто надавати трохи більше переваги терміну pollute. Це можна підтвердити й кількістю вживання похідних-термінів: contamination 2116 разів, а pollution - 6071 раз, contaminant $(s)-$ 1272 рази, а pollutant - 1942 рази. Варто зауважити, що внутрішня форма усіх згаданих термінів відповідає їхному лексичному значенню, адже суфікси -tion та -ant наявні в обох термінах і означають дію (процес) та, відповідно, речовину, яка забруднює довкілля. 
Як бачимо, часто один із синонімів починає домінувати, витісняючи інший на задній план, тому вважаємо за доцільне використовувати абсолютну частоту вживання термінів екомаркетингу як додатковий критерій уніфікування синонімів у терміносистемі екомаркетингу.

Таким чином, провівши цей аналіз, змушені погодитися з Л. Дрозд у тому, що повне усунення термінологічних синонімів 3 активного вжитку неможливе, а це так само унеможливлює абсолютну стандартизацію [14, с. 35].

Висновки i перспективи подальших розробок. Отже, аналіз термінів екомаркетингу в публіцистичних текстах показав, що будь-який публіцистичний текст екомаркетингу містить вузькогалузеві, міжгалузеві, зовнішньогалузеві терміни та загальновживану лексику, причому газетні статті, порівняно зі статтями спеціальних видань, містять набагато менше термінів. Також на основі проведеного аналізу було виділено три типи синонімічних рядів у терміносистемі екомаркетингу, найчастотнішим 3 яких $є$ ряд синонімів, які частково проявляються в публіцистичних текстах. Для впорядкування терміносистеми екомаркетингу важливим $є$ процес уніфікації синонімів, при цьому потрібно дотримуватися критеріїв вмотивованості та абсолютної частоти. Результати нашого дослідження можуть бути використанні у створенні галузевих словників, а також впорядкуванні терміносистеми екомаркетингу, що полегшить комунікацію фахівців цієї сфери. Перспективним вважаємо визначення семантичних особливостей термінів екомаркетингу в текстах інших жанрів.

\section{ЛІТЕРАТУРА}

1. Бондар О.М. Лінгвістичні особливості німецької фахової мови екології : дис. ... канд. філол. наук : 10.02.04. Київ : КНУ ім. Т.Г. Шевченка, 2015. $401 \mathrm{c}$.

2. Гордун С.М. Терміносистема екомаркетингу: структурно-семантичний та функціональний параметри (на матеріалі англомовної публіцистики) : дис. ... канд. філол. наук : 10.02.04. Запоріжжя. 2020. 295 c.

3. Вискушенко С.А. Термінологічна насиченість текстів англійської фахової мови тваринництва. URL: http://eprints.zu.edu.ua/14503/1/ Стаття.pdf (дата звернення: 18.02.2021).

4. Вовчанська С.І. Німецька фахова мова маркетингу: структурно-семантичний, лінгвопрагматичний та функціональний аспекти : дис. ... канд. філол. наук : 10.02.04. Івано-Франківськ, 2014. $396 \mathrm{c}$.

5. Вовчанська С.I. Функціонування синонімів та антонімів у термінології сучасної німецької мови. URL: http://www.academia. edu/22153796/ (дата звернення: 18.02.2021)
6. Кияк Т.Р. Мотивированность как возможный критерий отбора и упорядочения терминов-интернационализмов. Науч.-техн. информация. Сер. 1. 1985. № 10. С. 15-19.

7. Кияк Т.Р. Семантичні аспекти нормалізації термінологічних одиниць. Вісник Житомир. держ. ун-ту ім. І. Франка. 2008. № 38. С. 77-80.

8. Пономарів О.Д. Стилістика сучасної української мови. Тернопіль : Богдан, 2000. 248 с.

9. Цісар Н. До питання про варіантність і нормативність вторинних медичних найменувань. Вісник Нац. ун-ту «Львівська політехніка». Серія «Проблеми украӥнської термінологї̈» 2009. № 648. C. 61-65.

10. Aitchison J. Linguistics. London : Hodder\&Stoughton, Ltd., 2003. 92 p.

11. British National Corpus. URL: https://www. english-corpora.org/bnc/. (access date: 27.02.2021).

12. Cambridge Learner's Dictionary. URL: http:// dictionary.cambridge.org/dictionary/learnerenglish/. (access date: 15.02.2021).

13. COCA - Corpus of Contemporary American English. URL: http://corpus.byu.edu/coca/. (access date: 27.02.2021).

14. Drozd L., Roudny M. Language Planning and Standardization of Terminology in CzechoSlovakia. International Journal of Sociology of Language. Vol 23. Standardization of Nomenclature. The Hague, Paris, New York : Mouton Publishers, 1980. P. 29-42.

15. Voyant Tools. URL: https://voyant-tools.org/. (access date: 22.02.2021).

16. Wolseley R. Understanding magazines. Ames, 1966. $451 \mathrm{p}$.

\section{REFERENCES}

1. Bondar, O.M. (2015) Linhvistychni osoblyvosti nimetskoii fakhovoii movy ekolohiii [Linguistical peculiarities of German professional ecology language]: Candidate's thesis. Kyiv: KNU named after T.H. Shevchenka.

2. Hordun, S.M. (2020) Terminosystema ekomarketynhu: strukturno-semantychnyi ta funktsionalnyi parametry (na materiali anhlomovnoii publitsystyky) [Green marketing terminology system: structural, semantic and functional parameters (based on the English publicistic texts]: Candidate's thesis: 10.02.04. Zaporizhzhia.

3. Vyskushenko, S.A. Terminolohichna nasychenist tekstiv anhliyskoii fakhovoii movy tvarynnytstva [Terminological density of the English professional texts about animal husbandry]. URL: http://eprints.zu.edu.ua/14503/1/Cтаття.pdf

4. Vovchanska, S.I. Nimetska fakhova mova marketynhu: strukturno-semantychnyi, linhvoprahmatychnyi ta funktsionalnyi aspekty [German 
professional language of marketing: structural and semantical aspects]: Candidate's thesis. Ivano-Frankivsk.

5. Vovchanska, S.I. Funktsionuvannia synonimiv ta antonimiv u terminolohiii suchasnoii nimetskoii movy [Functioning of synonyms and antonyms in the modern German terminology]. Retrieved from URL: http://www.academia.edu/22153796/

6. Kyiak, T.R. (1985) Motyvatsiia yak mozhlyvyi kryterii vidboru ta vporyadkuvannia terminiv-internatsionalizmiv [Motivation as a possible criterion for selection and ordering of terms-internationalisms]. Nauchno-tekhnicheskaia informatsyia - Scientific and technical information, Vol. 1, 10, pp. 15-19.

7. Kyiak, T.R. (2008) Semantychni aspekty normalizatsiii terminolohichnykh odynyts [Semantic aspects of normalization of terminological units.]. Visnyk Zhytomyrskoho derzhavnoho universytetu imeni I. Franka - Bulletin of Zhytomyr State University named after I. Franko, Vol. 38, pp. 77-80.

8. Ponomariv, O.D. (2000) Stylistyka suchasnoii ukraiinskoii movy [Stylistics of the modern Ukrainian language]. Ternopil: Bohdan.
9. Tsisar, N. (2009) Do pytannia pro variantnist i normatyvnist vtorynnykh medychnykh naymenuvan [To the question of variability and normativeness of secondary medical names]. Visnyk Natsionalnoho universytetu «Lvivska politekhnika». Seriya «Problemy ukraiinskoii terminolohiii» - Bulletin of the National University «Lviv Polytechnic». Series «Problems of Ukrainian terminology». Lviv, Vol. 648. pp. 61-65.

10. Aitchison, J. (2003) Linguistics. London: Hodder\&Stoughton, Ltd..

11. British National Corpus. URL: https://www. english-corpora.org/bnc/

12. Cambridge Learner's Dictionary. URL: http://dictionary.cambridge.org/ dictionary/learner-english/

13. COCA - Corpus of Contemporary American English. URL: http://corpus.byu.edu/coca/

14. Drozd, L., Roudny, M. (1980) Language Planning and Standardization of Terminology in Czecho-Slovakia. International Journal of Sociology of Language. Standardization of Nomenclature. The Hague, Paris, New York, Vol. 23, pp. 29-42

15. Voyant Tools. URL: https://voyant-tools.org/

16. Wolseley, R. (1966) Understanding magazines. Ames, 1966. 